INTERNATIONAL JOURNAL
OHARMACEUTICAL SCIENCES
PESEARCH
RESED

Received on 15 August 2019; received in revised form, 10 April 2021; accepted, 19 May 2021; published 01 August 2021

\title{
STABILITY INDICATING METHOD DEVELOPMENT AND VALIDATION OF REMOGLIFLOZIN ETABONATE IN BULK AND PHARMACEUTICAL DOSAGE FORM BY RP-HPLC
}

\section{K. Likitha Kanna * and Uttam Prasad Panigrahy}

Department of Pharmaceutical Analysis, CMR College of Pharmacy, Kandlakoya (V), Medchal (District), Hyderabad - 501401, Telangana, India.

Keywords:

Remogliflozin Etabonate, RP-HPLC, C18 Column, Validation and ICH guidelines

\section{Correspondence to Author:}

Dr. Uttam Prasad Panigrahy

Department of Pharmaceutical Analysis, CMR College of Pharmacy, Kandlakoya (V), Medchal (District), Hyderabad - 501401, Telangana, India.

E-mail: uttampanigrahy@gmail.com

\begin{abstract}
An accurate, precise, and simple stability-indicating and RP-HPLC method was developed and validated for the estimation of Remogliflozin Etabonate in bulk and pharmaceutical dosage forms. Primacel $\mathrm{C}_{18}(150 \times 4.6 \mathrm{~mm}, 5 \mu \mathrm{m})$ column, with mobile phase Acetonitrile: Water (70:30, v/v) at isocratic mode, was used for the development of this method. At wavelength $280 \mathrm{~nm}$, and flow rate of $1 \mathrm{ml} / \mathrm{min}$ was maintained. The retention time for remogliflozin etabonate was about $2.6 \mathrm{~min}$. This method was validated with respect to $\mathrm{ICH}$ guidelines for linearity, the limit of detection, the limit of quantification, precision, accuracy, robustness, solution stability, and forced degradation studies. Linearity was performed in the concentration range of $25 \mu \mathrm{g} / \mathrm{ml}$ to $150 \mu \mathrm{g} / \mathrm{ml}$ with a correlation coefficient of 0.999 . The percentage recovery for Remogliflozin Etabonate was found to be within limits of $98 \%-102 \%$. The \%RSD was also found to be less than $2 \%$ which is within limits. Forced degradation studies result in maximum degradation occurred in alkali, acid, and peroxide degradation studies. There was no degradation occurred in photolytic and thermal degradation studies.
\end{abstract}

INTRODUCTION: Remogliflozin Etabonate is an anti-diabetic drug, chemically known as 5-Methyl4-[4-(1-methyl ethoxy) benzyl]-1-(1-methylethyl)1H-pyrazol-3-yl-6-O-(ethoxycarbonyl)- $\beta$-Dglucopyranoside. It inhibits the sodium-glucose transport proteins (SGLT), which are responsible for glucose reabsorption in the kidney. Blocking this transporter causes blood glucose to be eliminated through the urine. The structural formula is as shown in Fig. 1 $^{1-3}$.

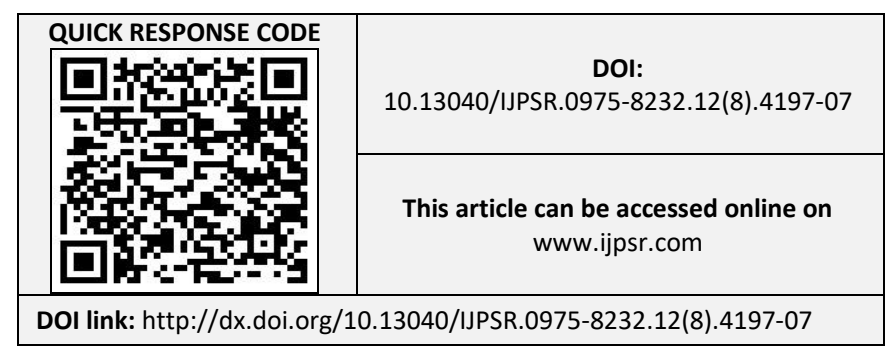

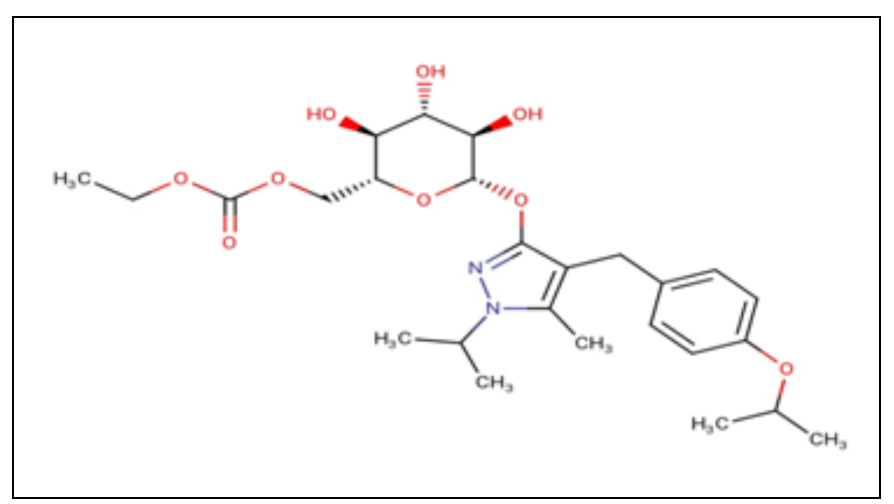

FIG. 1: CHEMICAL STRUCTURE OF REMOGLIFLOZIN ETABONATE

In the literature survey, it was found that there is no published literature for Remogliflozin Etabonate, but we found some articles for dapagliflozin, empagliflozin, and canagliflozin, which belong to the family of Remogliflozin ${ }^{4-17}$. In the present 
work, efforts are made to develop a simple, accurate, and precise RP-HPLC and solution stability method for Remogliflozin Etabonate in bulk and pharmaceutical dosage form and to validate it in accordance with ICH guidelines ${ }^{18,19}$.

MATERIALS AND METHODS: Remogliflozin Etabonate is a gift sample from Metrochem Pvt Ltd, Hyderabad, India. REMO ${ }^{\circledR}$-ZEN $100 \mathrm{mg}$
(Formulation was manufactured by Glenmark Pharma limited). HPLC grade chemicals were preferred for the development of the method; this was obtained for Merck, Hyderabad, India. The method development conditions are described in Table 1.

Selection of Wavelength: Wavelength was fixed at $280 \mathrm{~nm}$ by performing UV Spectroscopy Fig. 2.

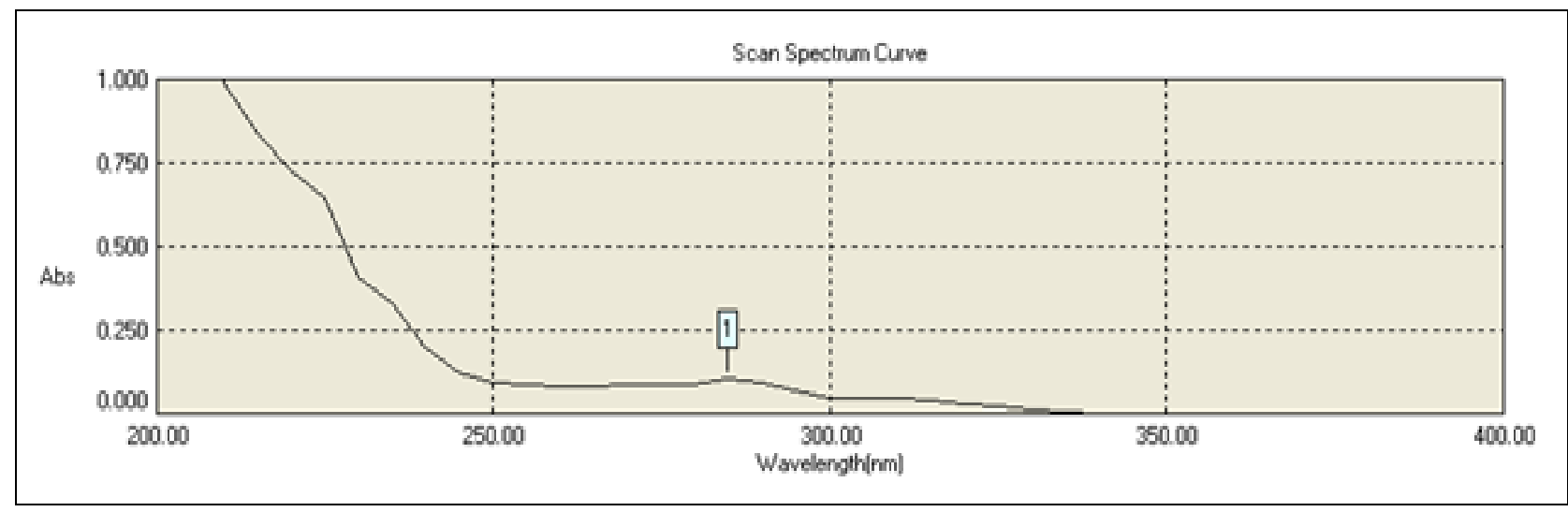

FIG. 2: WAVELENGTH SPECTRA

Chromatographic Conditions: Shimadzu HPLC with spinchrom software and UV/VIS detector with variable wavelength programme was used for the method development. Primacel $\mathrm{C}_{18}(150 \times 4.6 \mathrm{~mm}$, $5 \mu \mathrm{m})$ column. Acetonitrile: Water $(70: 30, \mathrm{v} / \mathrm{v})$ is used as mobile phase at a flow rate of $1 \mathrm{ml} / \mathrm{min}$ Rheodyne injector with $25 \mu$ l loop was used for injecting the sample, and the sample was analyzed at $280 \mathrm{~nm}$.

Preparation of Mobile Phase: $70 \mathrm{ml}$ of HPLC grade Acetonitrile is taken into a mobile phase reservoir, and $30 \mathrm{ml}$ of HPLC grade water is added to it, and then it is kept for sonication for 15 mins, sonicated, and degassed.

\section{Preparation of Standard Solution of} Remogliflozin Etabonate: 100mg API of Remogliflozin Etabonate is dissolved in $100 \mathrm{ml}$ solvent $(\mathrm{ACN})$ and the concentration is $1000 \mu \mathrm{g} / \mathrm{ml}$.

Preparation of Sample Solution: Estimation of Remogliflozin Etabonate $\left(\mathrm{REMO}^{\circledR}\right.$-ZEN) in dosage form, 20 tablets were weighed individually, and an average weight of the tablets was calculated and triturated into fine powder. $100 \mathrm{mg}$ equivalent powder is weighed and transferred it into a $100 \mathrm{ml}$ volumetric flask, then dissolve it using $30 \mathrm{ml}$ of a suitable solvent $(\mathrm{ACN})$ and sonicated it for $15 \mathrm{~min}$, then make up the volume of the contents in volumetric flask up to the mark using same solvent $(\mathrm{ACN})$ and filter it using Whatman filter paper (No. 1) the concentration obtained is $1000 \mu \mathrm{g} / \mathrm{ml}$. from this solution various sample solutions are prepared and validated according to ICH guidelines.

Preparation of Calibration Curve: From the standard solution pipette out $0.25 \mathrm{ml}, 0.5 \mathrm{ml}, 0.75 \mathrm{ml}$, $1 \mathrm{ml}, 1.25 \mathrm{ml} \& 1.5 \mathrm{ml}$ into respective $10 \mathrm{ml}$ volumetric flasks and make up the volume up to the mark using suitable solvent (ACN) the concentrations are $25 \mu \mathrm{g} / \mathrm{ml}, 50 \mu \mathrm{g} / \mathrm{ml}, 75 \mu \mathrm{g} / \mathrm{ml}$, $100 \mu \mathrm{g} / \mathrm{ml}, 125 \mu \mathrm{g} / \mathrm{ml}$ and $150 \mu \mathrm{g} / \mathrm{ml}$. then the solutions were injected thrice using $25 \mu 1$ injector at the flow rate $1 \mathrm{ml} / \mathrm{min}$, at $280 \mathrm{~nm}$ the chromatograms are recorded and calibration curve was plotted by taking concentration on $\mathrm{X}$-axis and peak area on Y-axis.

\section{Method Development:}

Trail 1: Theoretical plates are very less.

Trail 2: Theoretical plates are not within the limits.

Optimized chromatographic conditions: Theoretical plates are more than 2000 which are acceptable and within the limits and the retention time is $2.6 \mathrm{~min}$. 
TABLE 1: CHROMATOGRAPHIC CONDITIONS FOR METHOD DEVELOPMENT

\begin{tabular}{cccc}
\hline Parameters & Trail 1 & Trail 2 & Optimized Conditions \\
\hline Column & PRIMACEL C18 & PRIMACEL C18 & PRIMACEL C18 \\
& $(150 * 4.6 \mathrm{~mm}, 5 \mu \mathrm{m})$ & $(150 * 4.6 \mathrm{~mm}, 5 \mu \mathrm{m})$ & $(150 * 4.6 \mathrm{~mm}, 5 \mu \mathrm{m})$ \\
Mobile Phase & ACN $:$ Water $(50: 50, \mathrm{v} / \mathrm{v})$ & ACN $:$ Water $(60: 40, \mathrm{v} / \mathrm{v})$ & ACN $:$ Water $(70: 30, \mathrm{v} / \mathrm{v})$ \\
Flow Rate & $1 \mathrm{ml} / \mathrm{min}$ & $1 \mathrm{ml} / \mathrm{min}$ & $1 \mathrm{ml} / \mathrm{min}$ \\
Injection Volume & $25 \mu \mathrm{l}$ & $25 \mu \mathrm{l}$ & $25 \mu 1$ \\
Wavelength & $280 \mathrm{~nm}$ & $280 \mathrm{~nm}$ & $280 \mathrm{~nm}$ \\
Temperature & Ambient & Ambient & Ambient \\
Retention time & $2.6 \mathrm{~min}$ & $2.6 \mathrm{~min}$ & $2.6 \mathrm{~min}$ \\
Run time & $10 \mathrm{~min}$ & $10 \mathrm{~min}$ & $10 \mathrm{~min}$ \\
Theoretical Plates & 1842 & 1973 & 2139 \\
\hline
\end{tabular}

Assay Procedure: Remogliflozin Etabonate is available in the local pharmacy with the brand name of REMO ${ }^{\circledR}$-ZEN (100mg, Glenmark Pharma limited). $1000 \mu \mathrm{g} / \mathrm{ml}$ of sample solution was prepared and diluted to $50 \mu \mathrm{g} / \mathrm{ml}$ and was injected into the HPLC system, and its obtained peak areas were noted down, and its \% Assay was calculated as shown in Table 2.

TABLE 2: ASSAY OF FORMULATION

\begin{tabular}{cccc}
\hline Drug & $\begin{array}{c}\text { REMO }^{\circledR} \text {-ZEN Tablet } \\
\text { Label Claim (mg) }\end{array}$ & Amount Found (mg) & \% Label Claim \pm \% RSD (n=3) \\
\hline Remogliflozin Etabonate & 100 & 100.27 & $100.27 \pm 0.11$ \\
\hline
\end{tabular}

\section{RESULTS AND DISCUSSION:}

Specificity: The blank preparation from the formulation, which consists of excipients, was injected. Peaks were not detected in the retention time of analyte peak; this indicates that there is no interference of excipients of the formulation with the pure drug (API); this indicates that this method has specificity. The chromatogram is given in Fig. 3.
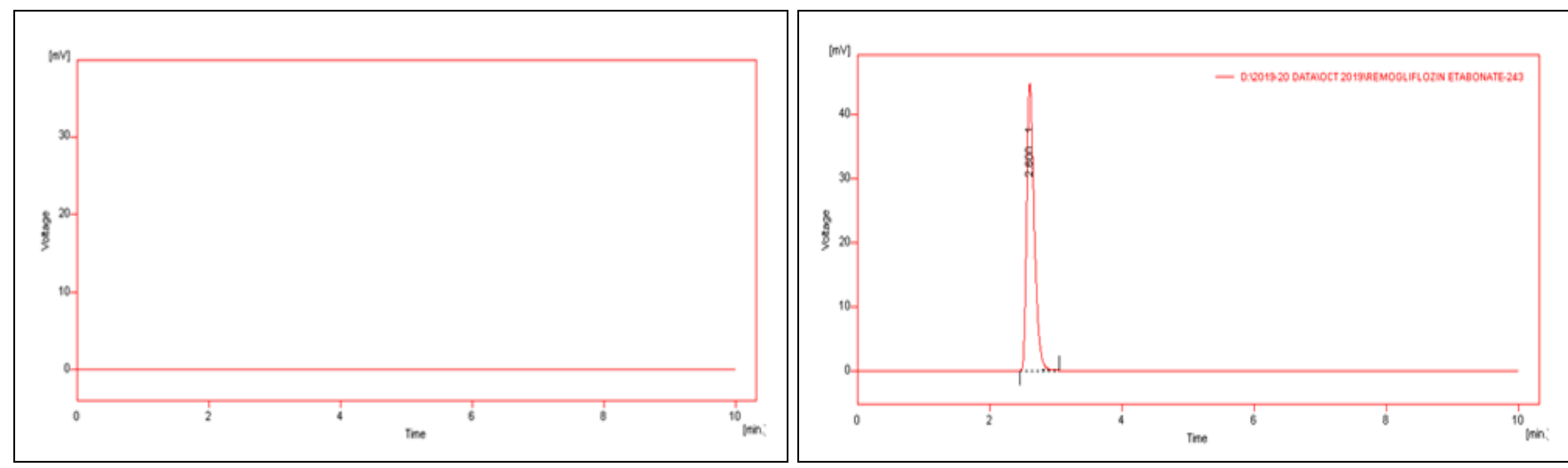

FIG. 3: BLANK AND STANDARD CHROMATOGRAM OF REMOGLIFLOZIN ETABONATE

Linearity: From the standard solution, a series of concentrations in the range of $25-125 \mu \mathrm{g} / \mathrm{ml}$ was prepared and injected thrice. The calibration curve

TABLE 3: PEAK AREAS OF REMOGLIFLOZIN ETABONATE

\begin{tabular}{cc}
\hline Concentration $(\boldsymbol{\mu g} / \mathbf{m l})$ & Peak Area $(\mathbf{m V})$ \\
\hline 25 & 75.633 \\
50 & 147.02 \\
75 & 221.147 \\
100 & 295.687 \\
125 & 369.122 \\
150 & 444.654 \\
Correlation Coefficient $\left(\mathrm{r}^{2}\right)$ & 0.9999 \\
\hline
\end{tabular}

was plotted by taking concentration on X Peak area on Y-axis. The obtained linearity has $\mathrm{r}^{2}=0.999$, as shown in Table 3 and Fig. 4.

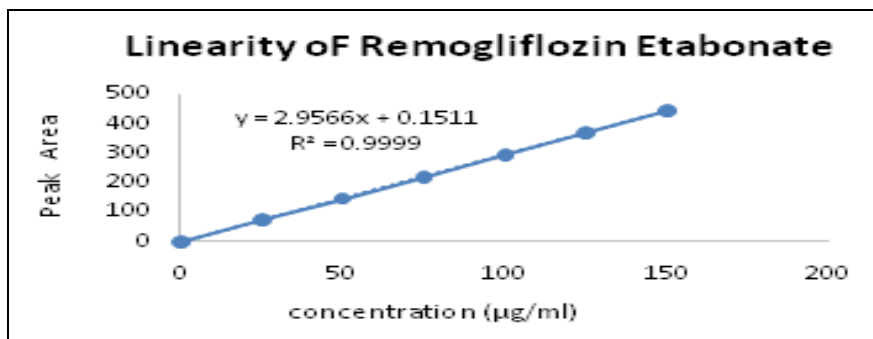

FIG. 4: CALIBRATION CURVE OF REMOGLIFLOZIN ETABONATE 
LOD: The limit of detection (LOD) was calculated according to the following formula results are discussed below.

$$
\begin{gathered}
\mathrm{LOD}=3.3 \times \text { Standard deviation } / \text { Slope } \\
\mathrm{LOD}=0.12 \mu \mathrm{g} / \mathrm{ml}
\end{gathered}
$$

LOQ: The limit of quantification was calculated according to the following formula results are discussed below.

$$
\begin{gathered}
\mathrm{LOQ}=10 \times \text { Standard deviation } / \text { Slope } \\
\mathrm{LOQ}=0.35 \mu \mathrm{g} / \mathrm{ml}
\end{gathered}
$$

Accuracy: Accuracy is described as an aggregate between the true value and the measured value. Accuracy was performed by injecting 50\%, $100 \%$ \& $150 \%$ levels thrice, and then its Amount found, Amount added, \%Recovery, Mean recovery, and $\%$ RSD were calculated and are discussed in Table 4.

TABLE 4: ACCURACY RESULTS OF REMOGLIFLOZIN ETABONATE

\begin{tabular}{ccccccc}
\hline Level & Amount Added $(\boldsymbol{\mu g} / \mathbf{m l})$ & Amount Found $(\boldsymbol{\mu g} / \mathbf{m l})$ & \% Recovery & \% Avg. Recovery & \% SD & \% RSD \\
\hline $50 \%$ & 25 & 25.12 & 100.48 & 100.81 & 0.870 \\
$50 \%$ & 25 & 25.45 & 101.80 & & \\
$50 \%$ & 25 & 25.03 & 100.15 & & \\
$100 \%$ & 50 & 49.10 & 98.21 & 99.74 & 1.550 \\
$100 \%$ & 50 & 49.89 & 99.70 & & \\
$100 \%$ & 50 & 50.65 & 101.31 & & \\
$150 \%$ & 75 & 74.43 & 99.33 & 100.20 & 0.805 \\
$150 \%$ & 75 & 75.27 & 100.36 & & 0.803 \\
$150 \%$ & 75 & 75.69 & 100.92 & & \\
\hline
\end{tabular}

\section{Precision: Repeatability:}

System Precision: It was performed by injecting $50 \mu \mathrm{g} / \mathrm{ml}$ of standard solution six times and its peak areas were noted and its average, SD, \% RSD was calculated as shown in Fig. 5 and Table 5.

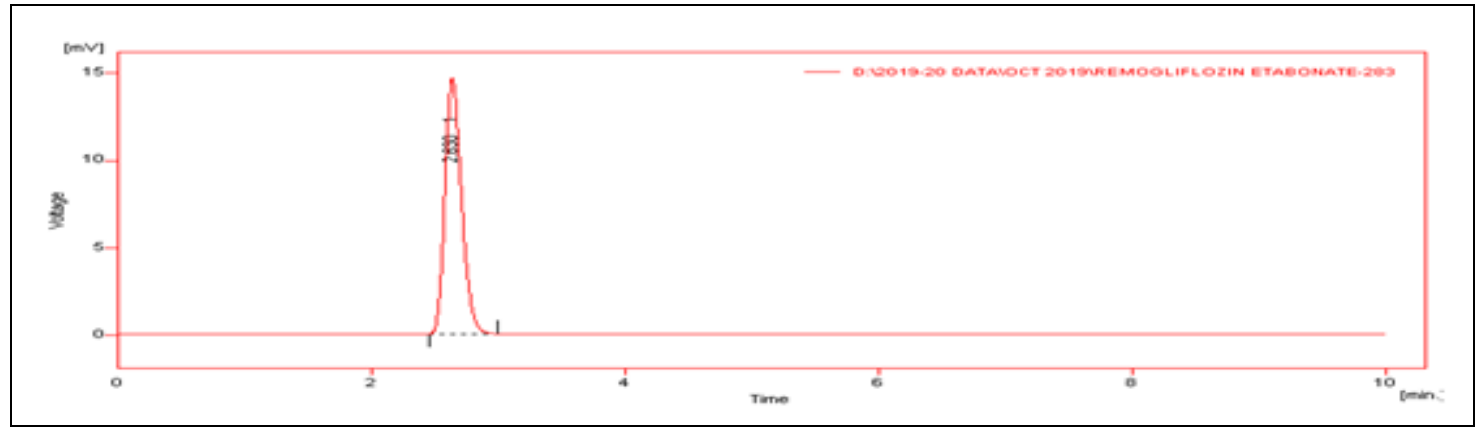

FIG. 5: CHROMATOGRAM FOR SYSTEM PRECISION OF REMOGLIFLOZIN ETABONATE

TABLE 5: RESULTS FOR SYSTEM PRECISION OF REMOGLIFLOZIN ETABONATE

\begin{tabular}{cccccc}
\hline Concentration $(\boldsymbol{\mu g} / \mathbf{m l})$ & Retention Time & Peak Area $(\mathbf{m V})$ & Average & S. D & \% RSD \\
\hline 50 & 2.6 & 152.892 & 152.649 & \\
50 & 2.6 & 154.435 & & \\
50 & 2.6 & 152.739 & & \\
50 & 2.6 & 153.691 & & \\
50 & 2.6 & 151.964 & & \\
50 & 2.6 & 150.173 & & \\
\hline
\end{tabular}

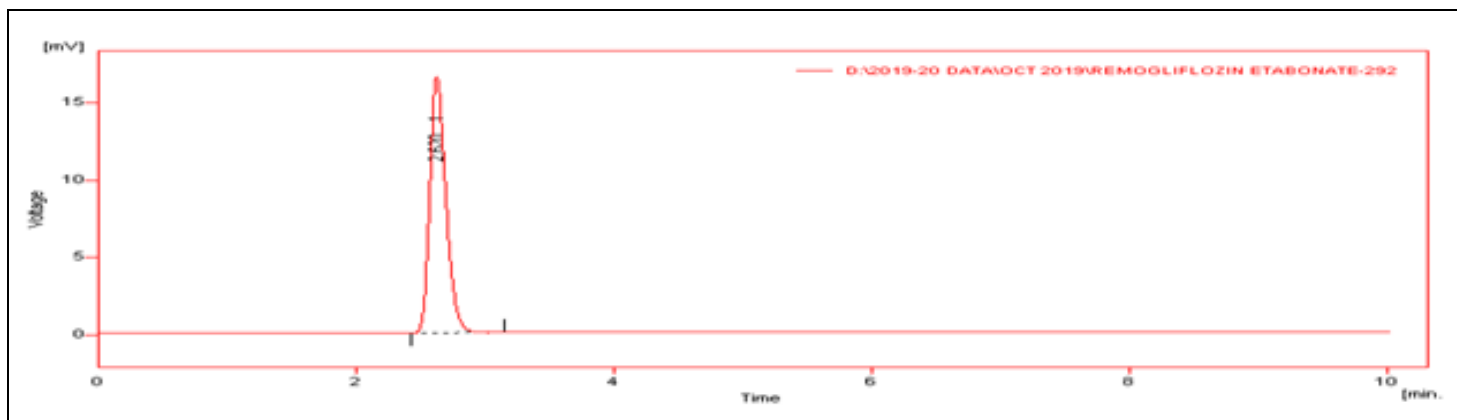

FIG. 6: CHROMATOGRAM FOR METHOD PRECISION OF REMOGLIFLOZIN ETABONATE 
Method Precision: It was performed by injecting $50 \mu \mathrm{g} / \mathrm{ml}$ of sample solution six times, and its peak areas were noted, and its \% Assay, Average, S. D
\& \%RSD were calculated as shown in Fig. 6 and Table 6.

TABLE 6: RESULTS FOR METHOD PRECISION OF REMOGLIFLOZIN ETABONATE

\begin{tabular}{ccccccc}
\hline Concentration $(\boldsymbol{\mu g} / \mathbf{m l})$ & Retention Time & Peak Area $(\mathbf{m V})$ & \%Assay & Average \% Assay & S. D & \%RSD \\
\hline 50 & 2.6 & 146.588 & 99.35 & 100.11 & 0.689 & 0.688 \\
50 & 2.6 & 149.378 & 100.65 & & & \\
50 & 2.6 & 147.942 & 100.27 & & \\
50 & 2.6 & 146.843 & 99.45 & & \\
50 & 2.6 & 149.295 & 101.10 & & \\
50 & 2.6 & 147.404 & 99.85 & & & \\
\hline
\end{tabular}

Ruggedness / Intermediate Precision: Ruggedness was performed on two different days by two different analysts in two different labs by maintained the same laboratory conditions. On Day 1, Analyst 1 and Analyst 2 injected $100 \%$ concentration of the sample $(50 \mu \mathrm{g} / \mathrm{ml})$ six times and noted its peak area values, and calculated its S. D \& \% RSD. Similarly, on Day 2, Analyst 1 and Analyst 2 injected $100 \%$ concentration of the sample $(50 \mu \mathrm{g} / \mathrm{ml})$ for six times, and its peak areas were noted and calculated for S. D \& \%RSD. The results are discussed in Table 7 and Fig. 7.

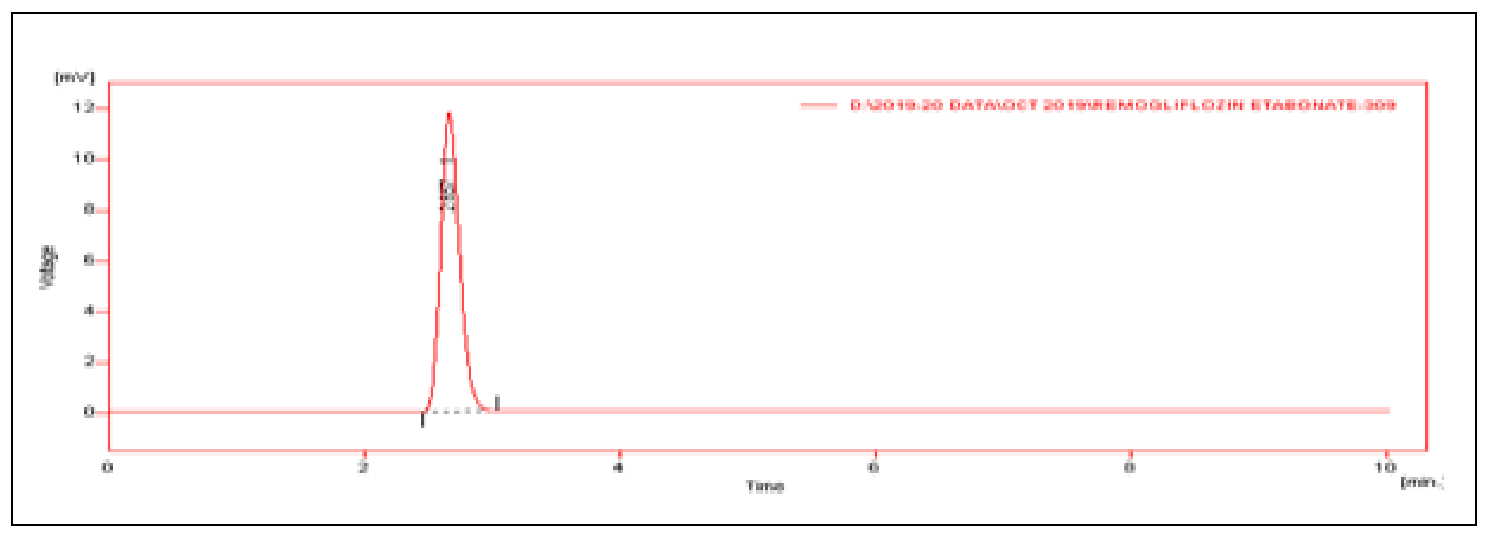

FIG. 7: CHROMATOGRAM FOR INTERMEDIATE PRECISION OF REMOGLIFLOZIN ETABONATE

TABLE 7: RESULTS FOR INTERMEDIATE PRECISION OF REMOGLIFLOZIN ETABONATE

\begin{tabular}{|c|c|c|c|c|c|c|c|c|}
\hline \multicolumn{5}{|c|}{ Lab-1 (\% Assay) } & \multicolumn{4}{|c|}{ Lab-2 (\% Assay) } \\
\hline \multirow{2}{*}{ Concentration $(\mu \mathrm{g} / \mathrm{ml})$} & \multicolumn{2}{|c|}{ Day-1 } & \multicolumn{2}{|c|}{ Day-2 } & \multicolumn{2}{|c|}{ Day-1 } & \multicolumn{2}{|c|}{ Day-2 } \\
\hline & A-1 & A-2 & A-1 & A-2 & A-1 & A-2 & A-1 & A-2 \\
\hline 50 & 100.32 & 99.72 & 99.08 & 99.12 & 101.84 & 99.80 & 102.08 & 98.57 \\
\hline 50 & 101.82 & 100.36 & 98.45 & 100.43 & 101.10 & 100.43 & 100.44 & 102.17 \\
\hline 50 & 100.82 & 99.75 & 99.83 & 102.32 & 99.43 & 99.48 & 101.96 & 99.71 \\
\hline 50 & 101.42 & 100.72 & 99.02 & 100.84 & 100.41 & 101.02 & 98.42 & 101.30 \\
\hline 50 & 101.12 & 100.30 & 100.65 & 102.23 & 99.08 & 102.19 & 98.86 & 100.16 \\
\hline 50 & 102.22 & 102.42 & 98.42 & 100.34 & 99.29 & 101.64 & 99.79 & 99.02 \\
\hline Average & 101.22 & 100.54 & 99.241 & 100.88 & 100.19 & 100.76 & 100.25 & 100.15 \\
\hline SD & 0.64 & 0.99 & 0.86 & 1.22 & 1.11 & 1.05 & 1.53 & 1.36 \\
\hline$\%$ RSD & 0.63 & 0.99 & 0.86 & 1.21 & 1.11 & 1.04 & 1.53 & 1.36 \\
\hline \multicolumn{9}{|c|}{ INTERMEDIATE PRECISION WITHIN LABORATORY VARIATIONS $(\mathrm{N}=6)$} \\
\hline \multicolumn{3}{|c|}{ Average } & \multicolumn{2}{|c|}{100.47} & \multicolumn{2}{|c|}{ Average } & \multicolumn{2}{|c|}{100.34} \\
\hline \multicolumn{3}{|c|}{$\mathrm{SD}$} & \multicolumn{2}{|c|}{0.865} & \multicolumn{2}{|c|}{ SD } & \multicolumn{2}{|c|}{0.282} \\
\hline \multicolumn{3}{|c|}{$\%$ RSD } & \multicolumn{2}{|c|}{0.861} & \multicolumn{2}{|c|}{$\%$ RSD } & \multicolumn{2}{|c|}{0.281} \\
\hline
\end{tabular}

Reproducibility: Precision between the laboratories is known as Reproducibility. The procedure was carried out by injecting the $100 \%$ concentration of the sample $(50 \mu \mathrm{g} / \mathrm{ml})$ for six times in two different laboratories into two different HPLC system. The peak areas were noted and its SD \& \%RSD was calculated which is discussed in Table 8 and Fig. 8. 


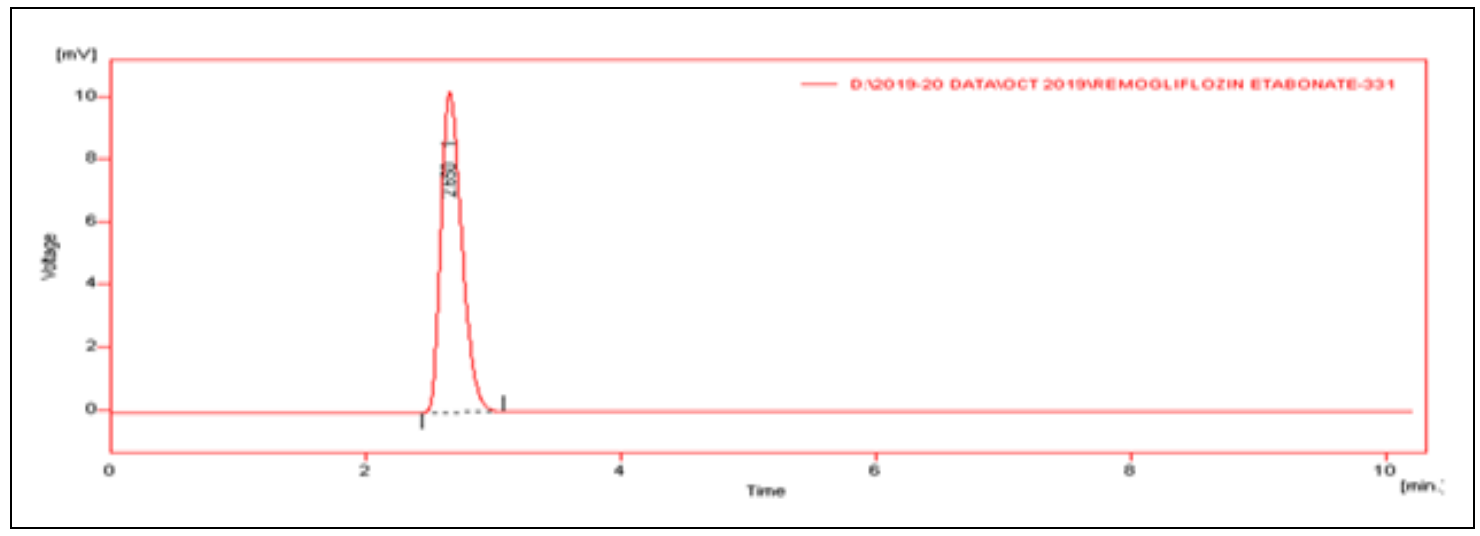

FIG. 8: CHROMATOGRAM FOR REPRODUCIBILITY OF REMOGLIFLOZIN ETABONATE

TABLE 8: RESULTS FOR REPRODUCIBILITY OF REMOGLIFLOZIN ETABONATE

\begin{tabular}{ccccc}
\hline & Lab-1 (\%Assay) & \multicolumn{3}{c}{ Lab-2 (\%Assay) } \\
\hline Average & & 100.47 & Average & 100.34 \\
SD & & 0.865 & SD & 0.282 \\
\%RSD & 0.861 & \%RSD & 0.281 \\
\hline \multicolumn{5}{c}{ REPRODUCIBILITY BETWEEN LABORATORIES (N=48) } \\
\hline & Average & 100.40 \\
& SD & 0.092 \\
& \%RSD & 0.091 \\
\hline
\end{tabular}

Robustness: Robustness is known as changes in conditions of the parameters that should not affect any method. So, robustness was performed by small changes in the parameter conditions of the mobile phase $( \pm 10 \%)$ and Flow rate $( \pm 10 \%)$.

Change in Mobile Phase: This procedure was carried out by changing the Mobile phase proportion $\pm 10 \%$ (i.e., 77:23, v/v and 63:37, v/v). $100 \%$ concentration $(50 \mu \mathrm{g} / \mathrm{ml})$ of sample solution was injected six times by varying the mobile phase proportions of $\mathrm{ACN}$ : water, i.e., 77:23, v/v and 63:37, v/v, its peak areas were noted and calculated for its \% Assay, Average, SD \& \%RSD as shown in Fig. 9 and 10 and Table 9 and $\mathbf{1 0 .}$

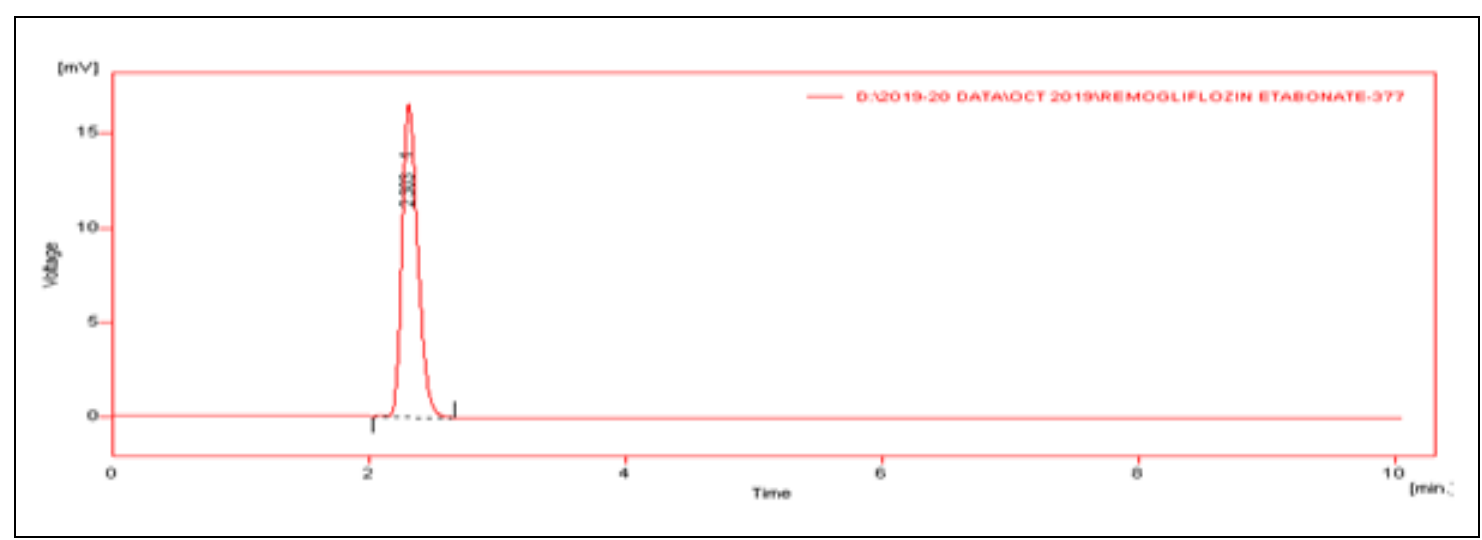

FIG. 9: CHROMATOGRAM FOR ROBUSTNESS AT +10\% OF MOBILE PHASE

TABLE 9: RESULTS FOR ROBUSTNESS + $10 \%$ OF MOBILE PHASE

\begin{tabular}{ccccccc}
\hline Concentration $(\boldsymbol{\mu g} / \mathbf{m l})$ & Retention Time $(\mathbf{m i n})$ & Peak Area $(\mathbf{m V})$ & \% Assay & Mean & SD & \%RSD \\
\hline 50 & 2.2 & 147.170 & 99.92 & 100.54 & 1.369 & 1.361 \\
50 & 2.2 & 145.665 & 98.90 & & & \\
50 & 2.2 & 149.777 & 101.69 & & \\
50 & 2.2 & 148.516 & 100.82 & & \\
50 & 2.2 & 146.586 & 99.53 & & \\
50 & 2.2 & 150.985 & 102.51 & & & \\
\hline
\end{tabular}




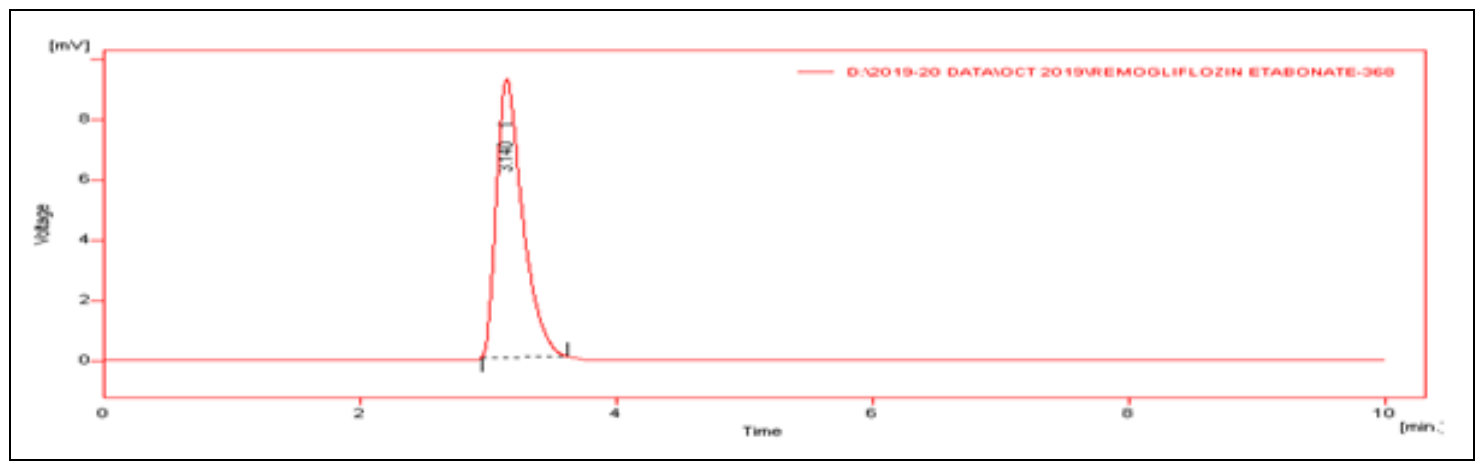

FIG. 10: CHROMATOGRAM FOR ROBUSTNESS AT -10\% OF MOBILE PHASE

TABLE 10: RESULTS FOR ROBUSTNESS AT -10\% OF MOBILE PHASE

\begin{tabular}{ccccccc}
\hline Concentration $(\boldsymbol{\mu g} / \mathbf{m l})$ & Retention Time $(\mathbf{m i n})$ & Peak Area $(\mathbf{m V})$ & \% Assay & Mean & SD & \%RSD \\
\hline 50 & 3.1 & 148.157 & 100.59 & 99.89 & 0.718 & 0.719 \\
50 & 3.1 & 147.572 & 100.20 & & & \\
50 & 3.1 & 146.197 & 99.26 & & & \\
50 & 3.1 & 146.880 & 99.73 & & & \\
50 & 3.1 & 148.225 & 100.66 & & & \\
50 & 3.1 & 145.666 & 98.90 & & & \\
\hline
\end{tabular}

Change in Flow Rate: This procedure was carried out by changing the flow rate proportion $\pm 10 \%$ $(0.9 \mathrm{ml} / \mathrm{min} \& 1.1 \mathrm{ml} / \mathrm{min}) \quad 100 \%$ concentration $(50 \mu \mathrm{g} / \mathrm{ml})$ of sample solution was injected six times by varying the Flow rate conditions i.e., $0.9 \mathrm{ml} / \mathrm{min}$ and $1.1 \mathrm{ml} / \mathrm{min}$, its peak areas were noted and calculated for its \%Assay, Average, SD \& \%RSD as shown in Fig. 11 and 12, Table 11 and 12.

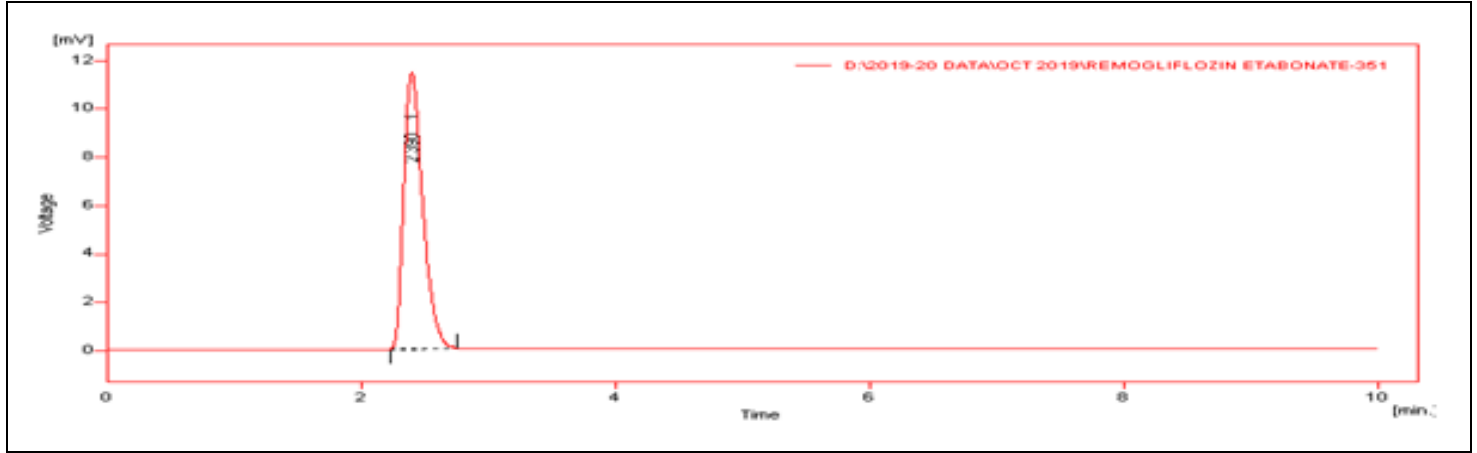

FIG. 11: PEAK ELUTED FOR ROBUSTNESS AT 1.1ml/min OF FLOW RATE

TABLE 11: RESULTS FOR ROBUSTNESS AT 1.1ml/min OF FLOW RATE

\begin{tabular}{|c|c|c|c|c|c|c|}
\hline Concentration $(\mu \mathrm{g} / \mathrm{ml})$ & Retention Time (min) & Peak Area $(\mathrm{mV})$ & \% Assay & Mean & SD & $\%$ RSD \\
\hline 50 & 2.3 & 146.221 & 99.28 & 100.22 & 1.08 & 1.08 \\
\hline 50 & 2.3 & 148.649 & 100.92 & & & \\
\hline 50 & 2.3 & 149.567 & 101.55 & & & \\
\hline 50 & 2.3 & 147.964 & 100.46 & & & \\
\hline 50 & 2.3 & 148.059 & 100.53 & & & \\
\hline 50 & 2.3 & 145.235 & 98.61 & & & \\
\hline
\end{tabular}

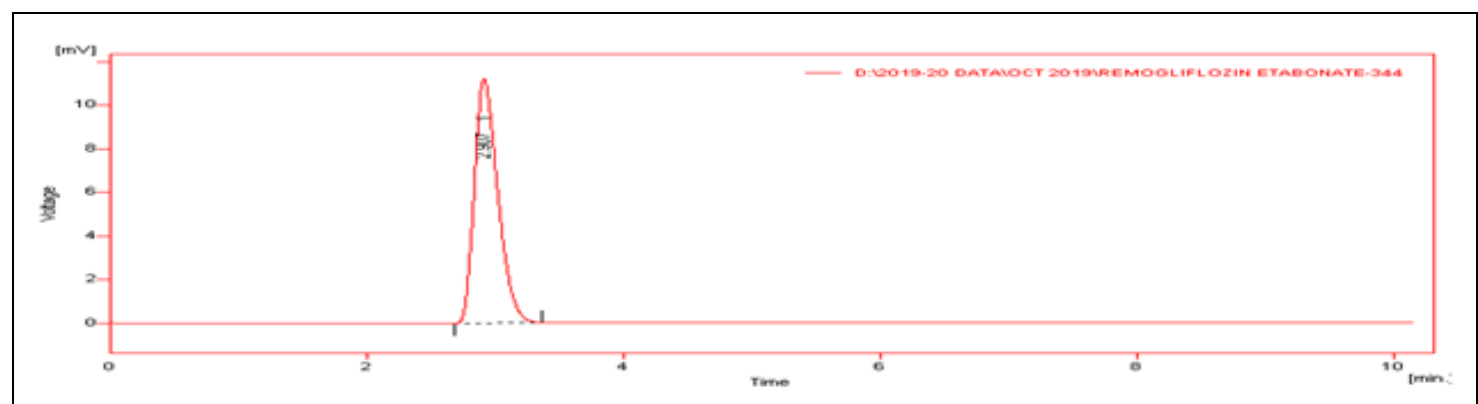

FIG. 12: PEAK ELUTED FOR ROBUSTNESS AT 0.9ml/min OF FLOW RATE 
TABLE 12: RESULTS FOR ROBUSTNESS AT 1.1ml/min OF FLOW RATE

\begin{tabular}{|c|c|c|c|c|c|c|}
\hline Concentration $(\mu \mathrm{g} / \mathrm{ml})$ & Retention Time (min) & Peak Area $(\mathrm{mV})$ & \% Assay & Mean & SD & $\%$ RSD \\
\hline 50 & 2.9 & 146.598 & 99.53 & 101.46 & 1.06 & 1.04 \\
\hline 50 & 2.9 & 150.724 & 102.34 & & & \\
\hline 50 & 2.9 & 151.954 & 102.42 & & & \\
\hline 50 & 2.9 & 149.512 & 101.51 & & & \\
\hline 50 & 2.9 & 148.963 & 101.14 & & & \\
\hline 50 & 2.9 & 149.972 & 101.82 & & & \\
\hline
\end{tabular}

Solution Stability: Solution stability was performed for $0 \mathrm{hr}, 24 \mathrm{~h}$ and $48 \mathrm{~h}$. $100 \%$ concentration $(50 \mu \mathrm{g} / \mathrm{ml})$ of sample solution was injected for six times at $0 \mathrm{~h}, 24 \mathrm{~h}$ and $48 \mathrm{~h}$. Peak areas obtained were noted and further calculation was done for \% Assay, SD and \%RSD was shown in Table 13 and Fig. 13, 14 and 15.

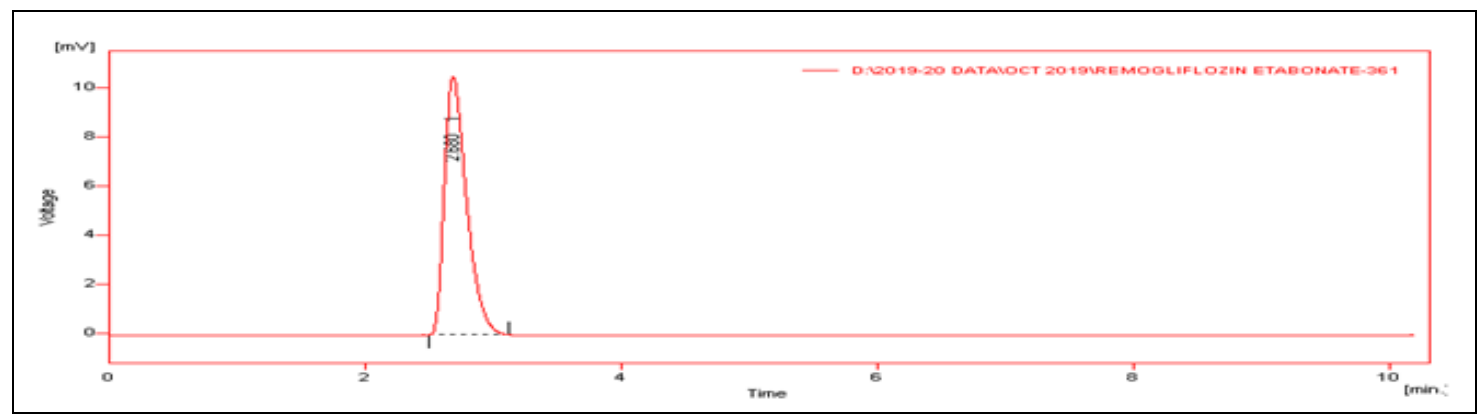

FIG. 13: PEAK ELUTED AT $0 \mathrm{~h}$

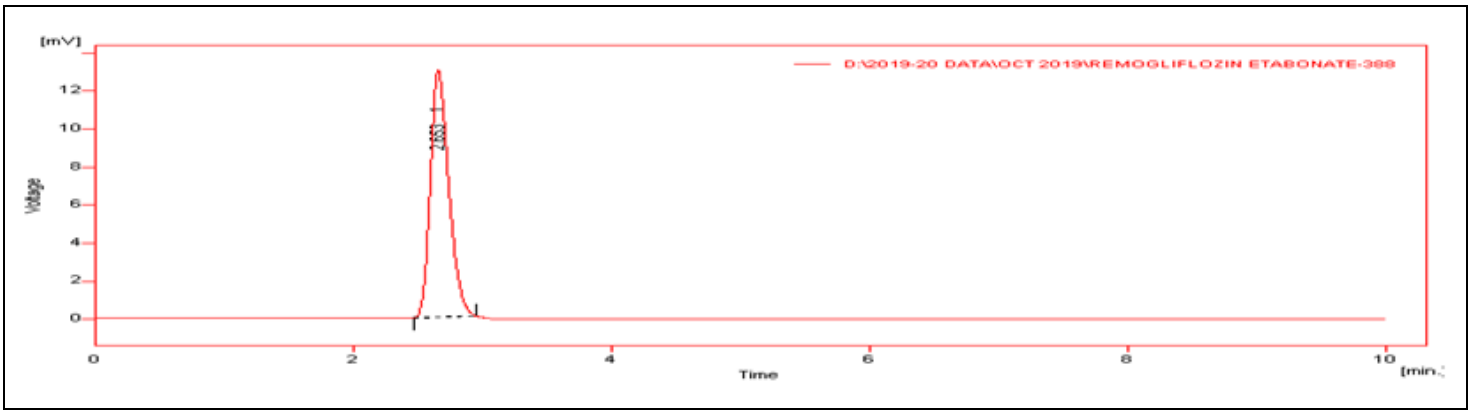

FIG. 14: PEAK ELUTED AT $24 \mathrm{~h}$

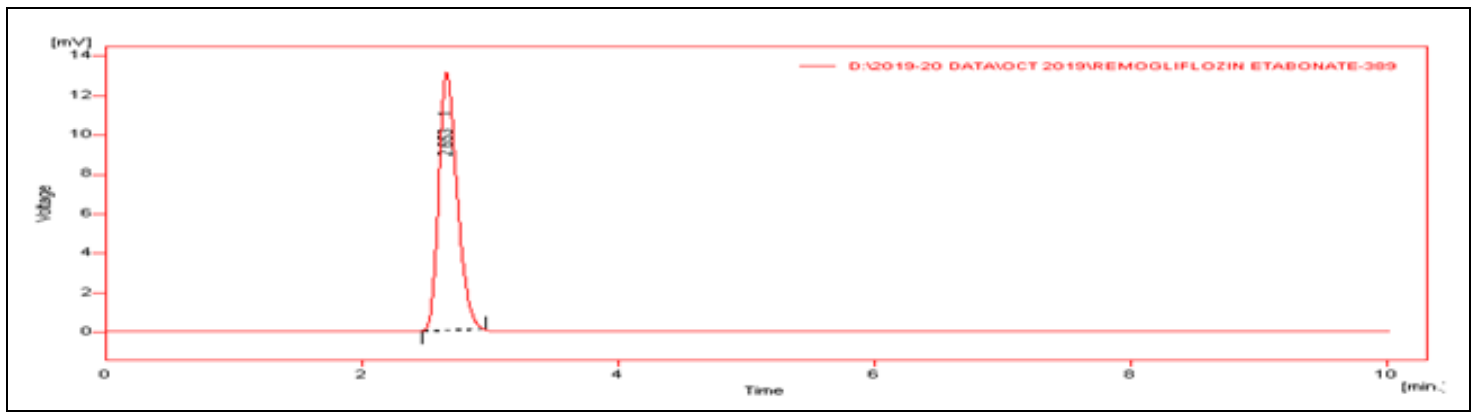

FIG. 15: PEAK ELUTED AT $48 \mathrm{~h}$

TABLE 13: RESULTS FOR SOLUTION STABILITY AT $0 \mathrm{~h}, 24 \mathrm{~h} \& 48 \mathrm{~h}$ FOR REMOGLIFLOZIN ETABONATE

\begin{tabular}{|c|c|c|c|c|c|c|c|}
\hline \multicolumn{4}{|c|}{ 0 Hour } & \multicolumn{2}{|c|}{24 Hours } & \multicolumn{2}{|c|}{48 Hours } \\
\hline $\begin{array}{c}\text { Concentration } \\
(\mu \mathrm{g} / \mathrm{ml})\end{array}$ & $\begin{array}{c}\text { Retention } \\
\text { Time (min) }\end{array}$ & $\begin{array}{c}\text { Peak Area } \\
(\mathrm{mV})\end{array}$ & \%Assay & $\begin{array}{c}\text { Peak Area } \\
(\mathrm{mV})\end{array}$ & \%Assay & $\begin{array}{c}\text { Peak Area } \\
(\mathrm{mV})\end{array}$ & \%Assay \\
\hline 50 & 2.6 & 147.134 & 99.90 & 147.152 & 99.91 & 149.474 & 101.42 \\
\hline 50 & 2.6 & 147.247 & 99.97 & 146.242 & 99.29 & 146.242 & 99.22 \\
\hline 50 & 2.6 & 146.634 & 99.56 & 148.190 & 100.61 & 148.770 & 100.92 \\
\hline 50 & 2.6 & 148.776 & 101.01 & 148.770 & 101.01 & 147.152 & 99.82 \\
\hline 50 & 2.6 & 145.369 & 98.70 & 149.474 & 101.49 & 145.534 & 98.72 \\
\hline 50 & 2.6 & 148.449 & 100.79 & 145.534 & 98.81 & 148.190 & 100.52 \\
\hline & & Mean & 99.98 & Mean & 100.18 & Mean & 100.10 \\
\hline & & S. D & 0.841 & S. D & 1.03 & S. D & 1.03 \\
\hline & & $\%$ RSD & 0.841 & $\%$ RSD & 1.03 & $\%$ RSD & 1.03 \\
\hline
\end{tabular}


Forced Degradation Studies: It was performed for Acid Degradation (0.1N HCl), Alkali Degradation $(0.1 \mathrm{~N} \mathrm{NaOH})$, Oxidative Degradation $\left(3 \% \mathrm{H}_{2} \mathrm{O}_{2}\right)$, Thermolytic Degradation $\left(60^{\circ} \mathrm{C}\right.$ Heating) \& Photolytic Degradation (sunlight).

\section{Solutions Preparation:}

0.1N HCl Preparation: $0.812 \mathrm{ml}$ of $\mathrm{HCl}$ is taken into a $100 \mathrm{ml}$ volumetric flask, and volume it made up to the mark using distilled water.

0.1N NaOH Preparation: 0.4 gm of Sodium Hydroxide pellets are taken into a $100 \mathrm{ml}$ volumetric flask, and volume is made up to the mark using distilled water.
3\% $\mathrm{H}_{2} \mathrm{O}_{2}$ Preparation: $3 \mathrm{ml}$ of $\mathrm{H}_{2} \mathrm{O}_{2}$ is pipetted out into a $100 \mathrm{ml}$ volumetric flask, and volume is made up to the mark using distilled water.

\section{Procedure:}

Acid Degradation Studies: From the stock solution $(100 \mu \mathrm{g} / \mathrm{ml})$, pipette out $5 \mathrm{ml}$ and add into a $10 \mathrm{ml}$ volumetric flask, to it add $1 \mathrm{ml}$ of the prepared $0.1 \mathrm{~N} \mathrm{HCl}$ and then make up the volume up to the mark using Acetonitrile then kept for 60 mins and inject the prepared sample for six times and check the peak area at optimized conditions shown in Fig. 16 and Table 14.

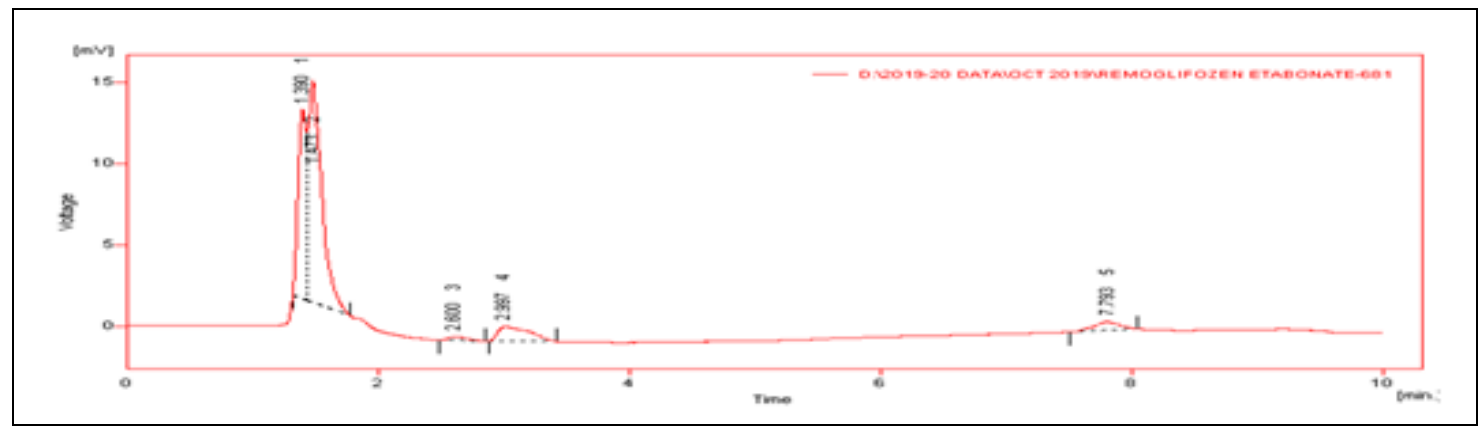

FIG. 16: PEAK ELUTED FOR ACID DEGRADATION

Alkali Degradation Studies: From the stock solution $(100 \mu \mathrm{g} / \mathrm{ml})$ pipette out $5 \mathrm{ml}$ and add into a $10 \mathrm{ml}$ volumetric flask, to it add $1 \mathrm{ml}$ of the prepared $0.1 \mathrm{~N} \mathrm{NaOH}$ and then make up the volume up to the mark using Acetonitrile then kept for $60 \mathrm{~min}$ and inject the prepared sample for six times and check the peak area at optimized conditions shown in Fig. 17 and Table 14.

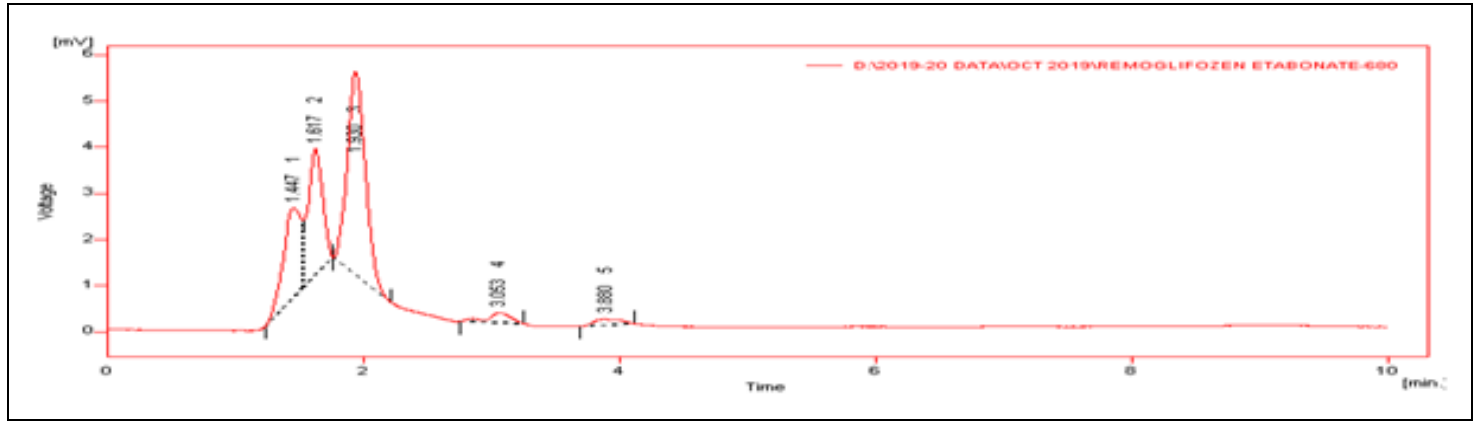

FIG. 17: PEAK ELUTED FOR ALKALI DEGRADATION

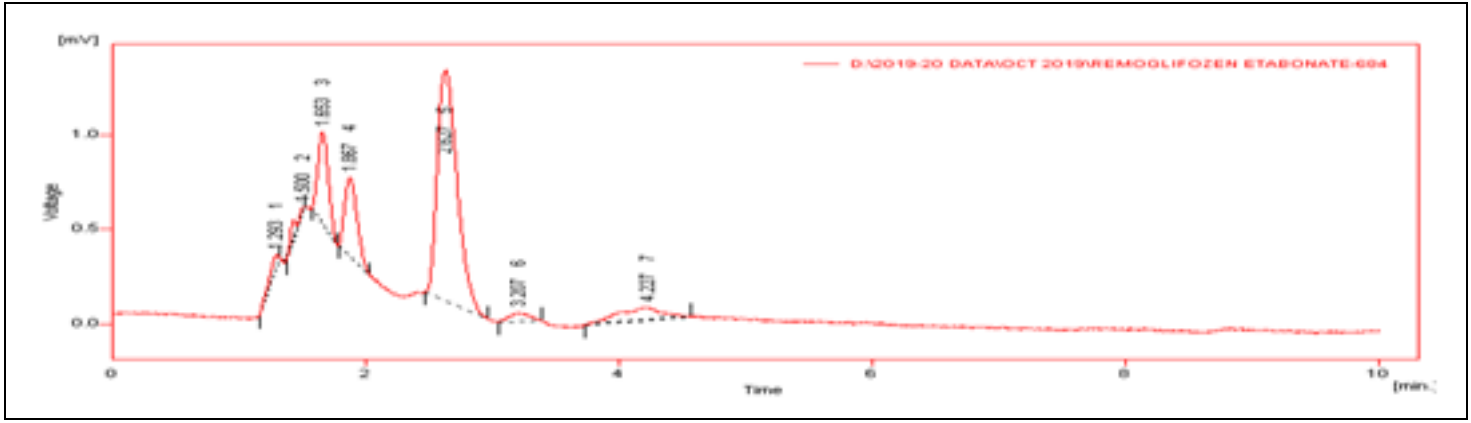

FIG 18: PEAK ELUTED FOR OXIDATIVE DEGRADATION 
Oxidative Degradation Studies: From the stock solution $(100 \mu \mathrm{g} / \mathrm{ml})$ pipette out $5 \mathrm{ml}$ and add into a $10 \mathrm{ml}$ volumetric flask, to it add $1 \mathrm{ml}$ of the prepared $3 \% \mathrm{H}_{2} \mathrm{O}_{2}$ and then make up the volume up to the mark using Acetonitrile then kept for 60 min and inject the prepared sample for six times and check the peak area at optimized conditions shown in Fig. 18 and Table 14.
Thermal Degradation Studies: From the stock solution $(100 \mu \mathrm{g} / \mathrm{ml})$ pipette out $5 \mathrm{ml}$ and into a $10 \mathrm{ml}$ volumetric flask and then make up the volume up to the mark using Acetonitrile and kept the solution in Hot air oven at $60^{\circ} \mathrm{C}$ for $60 \mathrm{~min}$ and inject the sample for six times and check the peak area at optimized conditions shown in Fig. 19 and Table 14.

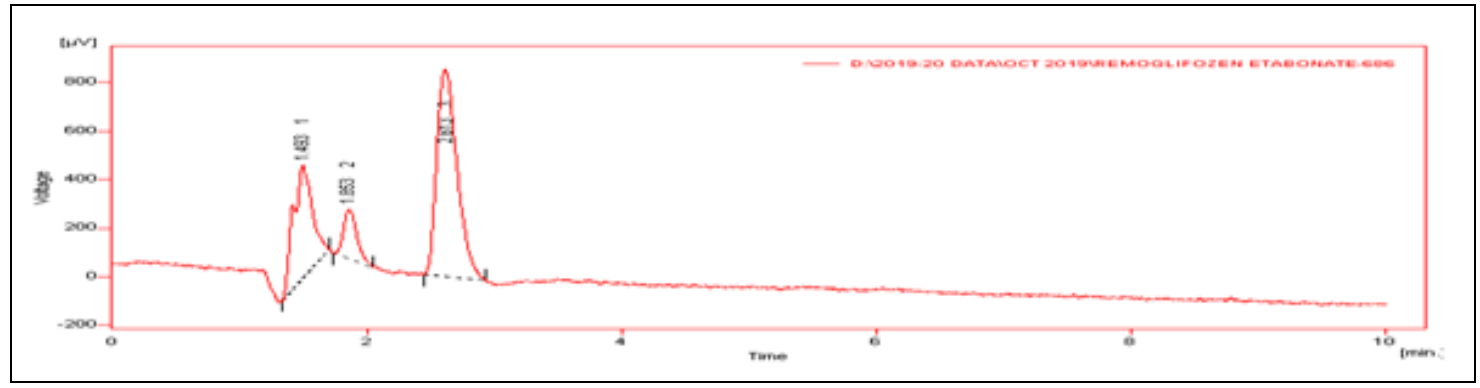

FIG. 19: PEAK ELUTED FOR THERMAL DEGRADATION

Photolytic Degradation Studies: From the stock solution $(100 \mu \mathrm{g} / \mathrm{ml})$ pipette out $5 \mathrm{ml}$ and add into a $10 \mathrm{ml}$ volumetric flask and then make up the volume up to the mark using Acetonitrile and kept the solution in UV chamber for $60 \mathrm{~min}$ and then inject the sample for six times and check the peak area at optimized conditions shown in Fig. 20 and Table 14.

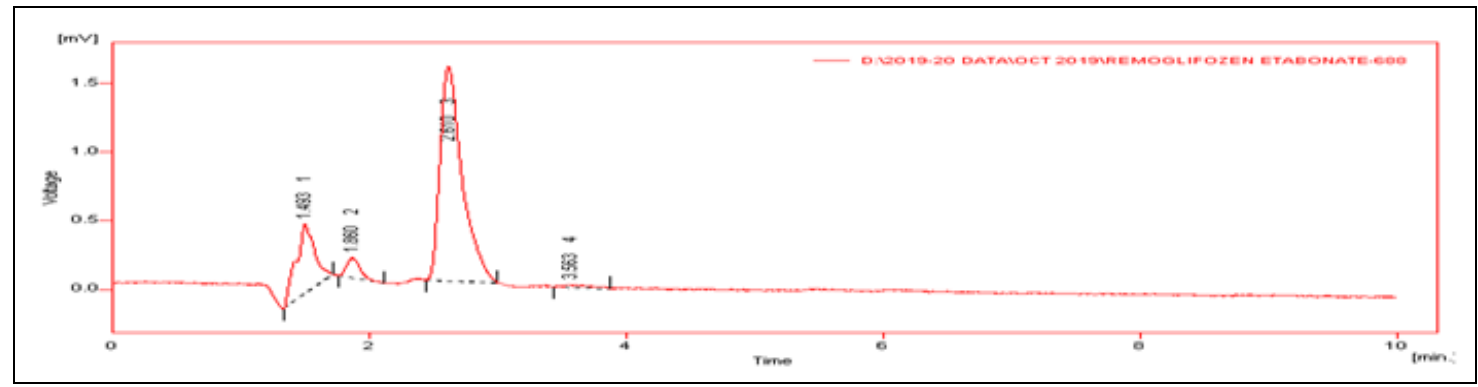

FIG. 20: PEAK ELUTED FOR PHOTOLYTIC DEGRADATION

TABLE 14: RESULTS FOR FORCED DEGRADATION STUDIES OF REMOGLIFLOZIN ETABONATE

\begin{tabular}{cccccc}
\hline Degradation parameter $(\mathbf{n}=\mathbf{3})$ & Concentration $(\boldsymbol{\mu g} / \mathbf{m l})$ & Peak Area $(\mathbf{m V})$ & Average & \%Degraded & \% Recovered \\
\hline Acid & 50 & 51.02 & 51.38 & 65.06 & 34.94 \\
& 50 & 52.08 & & & \\
Alkali & 50 & 51.04 & & & \\
& 50 & 41.02 & 41.38 & 71.86 & \\
& 50 & 42.04 & & & \\
Peroxide & 50 & 41.08 & & & \\
& 50 & 69.24 & 68.90 & 53.14 & \\
Thermal & 50 & 68.16 & & & \\
& 50 & 69.32 & & & \\
& 50 & 145.01 & 145.52 & & \\
& 50 & 146.23 & & & \\
& 50 & 145.32 & & & \\
& 50 & 146.34 & 146.52 & 0.35 & \\
\end{tabular}

From the above values, we can explain clearly that maximum degradation occurred in Alkali, Acid, and Peroxide. There was no degradation that occurred in Photolytic and Thermal.
CONCLUSION: From the obtained result, it was concluded that a simple, rapid, sensitive, linear, accurate, rugged, robust, and precise method was developed for the estimation of Remogliflozin 
Etabonate by HPLC. Various validation parameters like Specificity, Linearity, Precision, LOD, LOQ, Accuracy, Solution Stability, and Forced Degradation Studies were carried out. The linearity was obtained in the concentration range of $25 \mu \mathrm{g} / \mathrm{ml}$ - $150 \mu \mathrm{g} / \mathrm{ml}$ with correlation factor $\left(\mathrm{r}^{2}\right)$ 0.999. The $\%$ RSD for all the parameters was found to within limits i.e., less than $2 \%$, and $\%$ recovery was also found to within limits i.e., $98 \%$ - 102\%. Hence, it was concluded that the projected method can be used for the determination of Remogliflozin Etabonate by Stability indicating and RP-HPLC method.

ACKNOWLEDGEMENT: I would like to thank our Principal, Dr. K. Abbulu, CMR College of Pharmacy, Hyderabad, for providing all the necessary facilities. I express my deepest gratitude to Metrochem labs Pvt, Hyderabad, for providing the API of Remogliflozin Etabonate to facilitate the work. I take my pleasure to thank all the teaching and non-teaching staff members for their valuable support during my academics and project.

CONFLICTS OF INTEREST: The author declared that they have no conflicts of interest.

\section{REFERENCES:}

1. www.drugbank.ca/drugs/DB12935.

2. www.Pubchem.ncbi.nlm.nih.gov/compound/Remogliflozi n-etabonate.

3. www.en.m.Wikipedia.org/wiki/Remogliflozin etabonate.

4. Panigrahy UP and Reddy ASK: A Novel Validated RPHPLC-DAD Method for the Simultaneous Estimation of Metformin Hydrochloride and Canagliflozin in Bulk and Pharmaceutical Tablet Dosage form with Forced Degradation Studies. Oriental Journal of Chemistry 2015; 31(3): 1489-1507.

5. Debata J, Kumar S, Jha SK and Khan A: A new RP-HPLC method development and validation of Dapagliflozin in bulk and tablet dosage form. Int J Drug Dev \& Res 2017; 9: 48-51.

6. Basha SS and Sravanthi P: Development and validation of dapagliflozin by RP-HPLC method and its forced degradation studies. Asian Journal of Pharmaceutical and Clinical Research 2017; 10(11): 1-5.

7. Nirmala K, Mounika J and Nandin B: Validated stabilityindicating RP-HPLC method for determination of
Empagliflozin. Scholars Research Library 2016; 8(2): 457 64.

8. Geetha Susmita A, Rajitha G, Ramya Yadav Y and Uma P: Analytical method development \& validation of new stability indicating RP-HPLC Method for simultaneous estimation of Metformin $\mathrm{HCl} \&$ Empagliflozin in tablet dosage form. Asi J of Phar and Clin Res 2019; 12(1): 1-4.

9. Swamy GS, Lalitha R, Mounika Ch, Sowmya B and Kumar DS: A validated RP-HPLC method for simultaneous determination of Metformin and Canagliflozin in pharmaceutical dosage form. Asian Journal of Pharmaceutical Analysis 2018; 8(2): 73-77.

10. Suneetha A and Sharmila D: A validated stability indicating RP-HPLC method for estimation of Canagliflozin in dosage form. Research journal of Pharmaceutical Biological and Chemical Sciences 2015; 6(5): 1186-94

11. Mahesh A, Rafea Elamin EE, Rajasekaran S, Mohammed MI, Katharigatta NV, Sreeharsha N and Abdulmalek AB: Development and Validation of Rapid RP-HPLC and Green Second-Derivative UV Spectroscopic Methods for Simultaneous Quantification of Metformin and Remogliflozin in Formulation Using Experimental Design. Separations 2020; 59: 1-20.

12. Padmaja N and Veerabhadram G: Method Development and Validation of RP-HPLC Method for the Estimation of Empagliflozin in API. Int J Pharm Sci Res 2016; 7(2): 724-27.

13. Ahmad S, Usman MR, Shaikh T, Imran M and Akhtar R: Development and validation of UV spectrophotometric method for estimation of saxagliptin and dapagliflozin in bulk and dosage form. Int J Pharm Sci \& Res 2021; 12(4): 2185-92.

14. Mendhule RB, Warokar AS, Mahajan UN, Mahajan NM and Barde LN: New stability indicating UFLC method for simultaneous estimation of metformin $\mathrm{HCl}$ and vildagliptin in bulk and solid dosage form. Int J Pharm Sci \& Res 2021; 12(4): 2289-95.

15. Shrivastava $S$ and Kaur CD: Development and validation of novel UV spectrophotometric method for the determination of mebendazole in pharmaceutical formulation. Int J Pharm Sci \& Res 2021; 12(4): 2317-22.

16. Patil N and Sharannavar B: Simultaneous quantification of rosuvastatin and telmisartan in bulk and tablet - a validated UV-spectrophotometric technique. Int J Pharm Sci \& Res 2021; 12(4): 2485-91.

17. Veeshma A, Priyanka S, Kumar PK and Sirisha K: Simultaneous estimation of ciprofloxacin and metronidazole in bulk and tablet formulation by UVspectrophotometry. Int J Pharm Sci \& Res 2021; 12(4): 2247-56

18. ICH guidance, validation of analytical method: definition and terminology. International Conference on Harmonization Q2A Geneva.

19. ICH guidance, validation of analytical Procedures: Methodology. International Conference on Harmonization Q2B Geneva.

How to cite this article:

Kanna KL and Panigrahy UP: Stability indicating method development and validation of remogliflozin etabonate in bulk and pharmaceutical dosage form by RP-HPLC. Int J Pharm Sci \& Res 2021; 12(8): 4197-07. doi: 10.13040/IJPSR.0975-8232.12(8).4197-07.

All $\odot 2013$ are reserved by the International Journal of Pharmaceutical Sciences and Research. This Journal licensed under a Creative Commons Attribution-NonCommercial-ShareAlike 3.0 Unported License.

This article can be downloaded to Android OS based mobile. Scan QR Code using Code/Bar Scanner from your mobile. (Scanners are available on Google Playstore) 